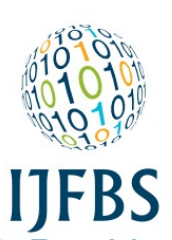

Finance \& Banking Studies

\section{Finance \& Banking Studies}

\author{
IJFBS, VOL 7 NO 4 ISSN: 2147-4486
}

Contents available at www.ssbfnet.com/ojs

https://doi.org/10.20525/ijfbs.v7i4.200

\title{
The Impact of the Tax Cuts and Jobs Act of 2017 on the US Government Debt
}

\author{
Min Xu \\ Corresponding Author, College of Business Administration, University of Detroit Mercy, Detroit, \\ MI, USA. Phone: (313)993-1225
}

ORCID ID: https://orcid.org/0000-0002-5618-633X

\section{Jeanne M. David}

College of Business Administration, University of Detroit Mercy, Detroit, MI, USA. Phone: (313)993-3325

\section{Suk Hi Kim}

College of Business Administration, University of Detroit Mercy, Detroit, MI, USA. Phone:

(313)993-1264

\begin{abstract}
There have been three major tax cuts in the modern US history: 1) the Tax Cuts and Jobs Act of 2017; 2) the Economic Growth and Tax Relief Reconciliation Act of 2001; and 3) the Economic Recovery Act of 1981. Each of the first two major tax cuts had increased the federal debt. Just about everybody agrees that US federal debt is on an unsustainable path. Can we afford another major tax cut without trigging a major economic disaster such as the Great Recession of 2007-2009? This article discusses an overview of this new law, the impact of the first two major tax cuts on the federal debt, the impact of the Tax Cuts and Job Acts on the US government debt, and its consequences.
\end{abstract}

Key words: tax cut, government debt, budget deficit

JEL Classification: E43, E44, E62 


\section{Introduction}

On December 22 2017, President Trump signed the Tax Cuts and Jobs Act of 2017 into law. The size of the tax cut and changes in the tax law under the Tax Cuts and Jobs Act (TCJA) are bigger and more comprehensive than those of the Economic Growth and Tax Relief Reconciliation Act of 2001 under President Bush. That is why experts say that TCJA proposes the most significant changes in US tax law since the Economic Recovery Act of 1981 by President Reagan, which many regarded as the biggest in US history and most comprehensive in the US history (Frankel, 2017).

In December 2017 Congress passed, and the President signed into law, the Tax Cuts and Jobs Act - the most significant combination of Federal tax cuts and comprehensive tax reform the United States has experienced in decades. The TCJA had four goals (The Council of Economic Advisors, 2018): 1) tax relief for middle-income families; 2) simplification for individuals; 3) economic growth through business tax relief; and 4) repatriation of overseas earnings. Key findings of Tax Foundation about the TCJA (Preliminary details and analysis of the Tax Cuts and Jobs Act, 2017) are as follows:

- "The Tax Cuts and Jobs Act would reform both individual income and corporate income taxes and would move the United States to a territorial system of business taxation.

- According to the Tax Foundation's Taxes and Growth Model, the plan would significantly lower m arginal tax rates and the cost of capital, which would lead to a 1.7 percent increase in GDP over $t$ he long term, 1.5 percent higher wages, and an additional 339,000 full-time equivalent jobs.

- The Tax Cuts and Jobs Act is a pro-growth tax plan, which would spur an additional \$1 trillion in fe deral revenues from economic growth, with approximately $\$ 600$ billion coming from the bill's perm anent provisions and approximately $\$ 400$ billion from the bill's temporary provisions over the budg et window. These new revenues would reduce the cost of the plan substantially. Depending on th e baseline used to score the plan, current policy or current law, the new revenues could bring the plan closer to revenue neutral.

- Over the next decade, the Tax Cuts and Jobs Act would increase GDP by an average of 0.29 per cent per year; GDP growth would be, on average, 2.13 percent, compared to 1.84 percent. In 201 8, GDP growth would be 0.44 percent over the baseline forecast.

- On a static basis, the plan would lead to 0.3 percent lower after-tax income on average for all taxpayers and 0.6 percent lower after-tax income on average for the top 1 percent in 2027, due to the expiration of the majority of the individual income tax cuts, but retention of chained CPI. When accounting for the increased GDP, after-tax incomes of all taxpayers would increase by 1.1 percent in the long run."

The April 30, 2018 headline news of Bloomberg and other news media was "The U.S. just borrowed $\$ 488$ billion, a record high for the first quarter." The U.S. Treasury borrowed $\$ 488$ billion from January through to March 2018. During the first three months of the year, the department borrowed about $\$ 47$ billion more than it had previously estimated. According to the Congressional Budget Office (CBO), tax and spending measures approved by Congress and President Donald Trump in December 2017 are expected to push the budget gap to $\$ 804$ billion in the current fiscal year, increasing from $\$ 665$ billion in 2017, and then surpassing \$1 trillion by 2020 (Mohsin \& Wood, 2018; Wood, 2018). On October 4, 2018, the CBO reported that the overall federal deficit of 2018 soared to $\$ 826$ billion, or 4.1 percent of the GDP, from 2.4 percent in 2017. The Trump administration has brushed off concerns about the deficit, but economists, more or less, disagreed. It is important to note that the actual deficit of 2018 was $\$ 24$ billion larger than the estimated deficit of 2018 ( $\$ 826$ billion - $\$ 804$ billion) (Elis, 2018).

Of course, higher projected deficits will lead to higher levels of debt. On February 18, 2018, the federal government's gross debt exceeded $\$ 20$ trillion (about 100 percent of the gross national product) for the first time in US history. This number represents an important reminder of America's unsustainable rising national 
debt. At the same time, the nominal amount of gross debt is just one of several measures of debt and is actually considered less economically meaningful than some other measures such as debt held by the public as a share of gross domestic product (GDP). This explains why we need to know about the different measures of debt and what they mean for the government's fiscal situation (Schroder, 2018).

The words 'debt' and 'deficit' come up frequently in debates and conversations about the policy decisions that lawmakers face. The two concepts are similar but are often confused. So, what exactly are the differences between the deficit and the debt? Deficits are how much the country borrows each year. The federal government runs a deficit when outlays (i.e., spending) exceed revenue, and it must borrow money to make up the difference. The U.S. government has run a deficit every year since 1970 , with the exception of four fiscal years (1998-2001). In 2018, the deficit is expected to be approximately $\$ 840$ billion, which is 4.2 percent of the gross domestic product (GDP). The debt is the total amount of money the U.S. government owes. It represents the accumulation of past deficits, minus surpluses. In other words, it reflects how much the government has borrowed over its history.

The phrases 'public debt' and 'intragovernmental debt' also come up frequently in debates and conversations about the policy decisions that lawmakers face. These two types of debt make up the national debt. The national debt is also known as the gross national debt, sovereign debt, country debt, or government debt. The public debt is the debt held by the public, such as Treasury securities held by investors outside the federal government. This includes those held by individuals, corporations, the Federal Reserve System, and foreign, state, and local governments. Intragovernmental debt is the debt held by government accounts, non-marketable Treasury securities held in accounts of programs administered by the federal government, such as the Social Security Trust Fund. Debt held by government accounts represents the cumulative surpluses, including interest earnings, of various government programs that have been invested in Treasury securities.

On March 5 2018, the total U.S. debt surpassed \$21 trillion, making the debt-to-GDP ratio 101 percent based on the first quarter GDP of $\$ 20.9$ trillion. The public debt was a more moderate $\$ 15.2$ trillion, making the public debt-to-GDP ratio a safe 73 percent (Government, 2018). In the short term, public debt is a good way for countries to get extra funds to invest in their economic growth. Public debt is a safe way for foreigners to invest in a country's growth by buying government bonds. This is much safer than foreign direct investment. On the other hand, public debt is bad when governments tend to take on too much debt because the benefits make them popular with voters. Therefore, investors usually measure the level of risk by comparing debt to a country's total economic output, known as gross domestic product (GDP). The debtto-GDP ratio gives an indication of how likely it is that the country will be able to pay off its debt. Investors usually don't become concerned until the debt-to-GDP ratio reaches a critical level. A debt-to-GDP ratio of 60 percent is often regarded as a critical level for developed countries. For developing and emerging economies, a debt-to-GDP ratio of 40 percent is considered to be a critical level (Chowdhury \& Islam, 2010).

\section{Causes of the Rising Federal Debt}

Figure 1 shows the US federal debt as a percentage of the gross domestic product from 1960 to 2018 . Each shaded bar represents a recession, which is defined as two consecutive quarters of decline in quarterly real (inflation-adjusted) gross domestic product. The width of each bar represents the length of the recession. The width of the last recession, also known as the Great Recession, is the largest of the seven recessions that the US has experience since 1960. According to the U.S. National Bureau of Economic Research (the official arbiter of U.S. recessions), the recession began in December 2007 and ended in June 2009, and thus extended over eighteen months. 


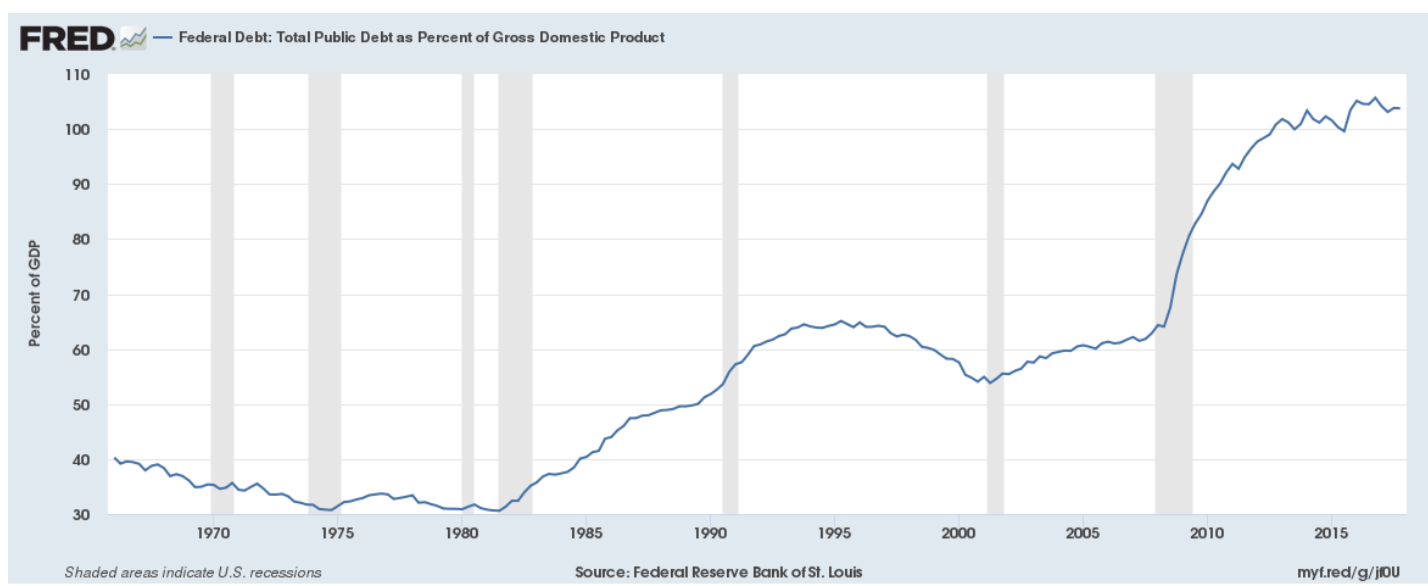

Figure 1: The US Federal Debt as Percent of Gross Domestic Product

Source: Federal Reserve Bank of St. Louis, Retrieved from https://fred.stlouisfed.org/series/GFDEGDQ188S

We will use Figure 1 to trace key causes of the rising federal debt as percent of the GDP. GDP had slowly declined from 1960 until just before the 1980-1982 recession. The year 1981 was an excellent time for a major tax cut along with a military buildup for a number of reasons: 1) the US had a major recession; 2) the federal debt as percent of GDP was the lowest since 1960; and the Soviet Union continued the expansion of its nuclear forces and power in half a dozen countries in Eastern Europe and Africa.

Major shifts in US macroeconomic policies since the early 1980s are primarily responsible for the mounting US debt. Critics charge that "Bush II repeated Reagan's performance and turned the national debt upward again." An increase of the U.S. debt by $\$ 1.35$ trillion over a 10 -year period and a military buildup larger than during the Cold War shifted the government budget from a record surplus of $\$ 387$ billion (predicted a few years earlier for 2004) to an actual record deficit of $\$ 412$ billion in 2004 (Neal, 2003; The Council of Economic Advisors (2017).

Why did critics charge that "Bush II repeated Reagan's performance and turned the national debt upward again?" The tax cut of 1981, which many regarded as the biggest in US history, reduced revenue growth. The military buildup in the same year, again regarded as the largest in US history, caused Federal outlays to rise suddenly. Such major shifts in US economic policies during the first half of the 1980 s caused Federal debt to increase from $\$ 908$ billion in 1980 (33 percent of the GDP) to $\$ 2.6$ trillion in 1988 (or 52 percent of the GDP) (The Council of Economic Advisors, 1985-1989).

In August 1981, with the U.S. at the beginning of a recession (see Figure 1), President Ronald Reagan signed major tax cuts into law. Reagan's supporters credited the cuts in tax rate and the military buildup to the unusually strong performance of both the U.S. economy and its stock market during the 1980s. The downside was obvious: less money flowing into the government's coffers. A US Treasury paper shows the 1981 act reduced federal revenue by an average of $\$ 118$ billion a year (in today's dollars) during the first four years (Kim, Crick \& Jia, 2008; Committee for a Responsible Federal Budget, 2017).

The early 2000s were also a good time for a major tax cut because the US had a recession from March 2001 to November 2001 and the federal debt as percent of GDP declined from 0.67 percent in 1995 to 0.57 percent in 2001. Thus, President George W. Bush also cut taxes in 2001 and 2003. Individualincome tax rates and taxes on capital gains and dividends were cut. President Barack Obama extended the cuts for two years in 2010 and made most of them permanent in 2012. The cuts originally enacted during the Bush years would account for $\$ 5$ trillion of debt outstanding through the fiscal year 2017. The year-and-a-half long Great Recession began in December 2007, brought on by the collapse of the U.S. housing market. The downturn spanned the Bush and Obama presidencies, and heralded the ballooning 
of budget deficits as the government responded with huge bank bailout and stimulus programs. In the fiscal years 2009-2012 deficits exceeded \$1 trillion (CBO Budget and Economic Outlook 2009-2019, 2016).

The US spent heavily on the wars in Afghanistan - which the US invaded after the September 11, 2001 terrorist attacks - and Iraq. The nation's longest and most expensive war is the one that is still going on. In addition to nearly 7,000 troops killed, the 16-year conflict in Iraq and Afghanistan cost an estimated US\$6 trillion due to its prolonged length, rapidly increasing veterans' health care and disability costs, and interest on war borrowing. The U.S. still has to confront the staggering cost and the challenge of paying for this war (Bilmes, 2017).

\section{Budget Deficits and Debt}

Figure 2 shows the Tax Policy Center estimate of the annual changes in GDP and budget deficit over the 2018-2027 period under the Senate version of the bill in December 2017. The cumulative GDP increase of $\$ 961$ billion is less than the deficit increases of $\$ 1,233$ billion, including macroeconomic feedback effects. This means that the bill would increase the national debt by only $\$ 272$ billion for 10 years from 2018 to 2027 or $\$ 27.2$ billion per year. It is important to note that the December 2017 Senate version of the bill became the Job Growth and Tax Cut. However, the Congressional Budget Office (CBO) estimated in April 2018 that implementing the Tax Act would add an estimated $\$ 2.289$ trillion to the national debt over ten years, or about $\$ 1.891$ trillion ( $\$ 15,000$ per household) after considering macroeconomic feedback effects, in addition to the $\$ 9.8$ trillion increase forecast under the current policy baseline and the existing $\$ 20$ trillion national debt. Debt held by the public as a percentage of GDP would rise from around 77 percent GDP in 2017 to as much as 105 percent GDP by 2028 (The Budget and Economic Outlook: 2018-2028, 2018).

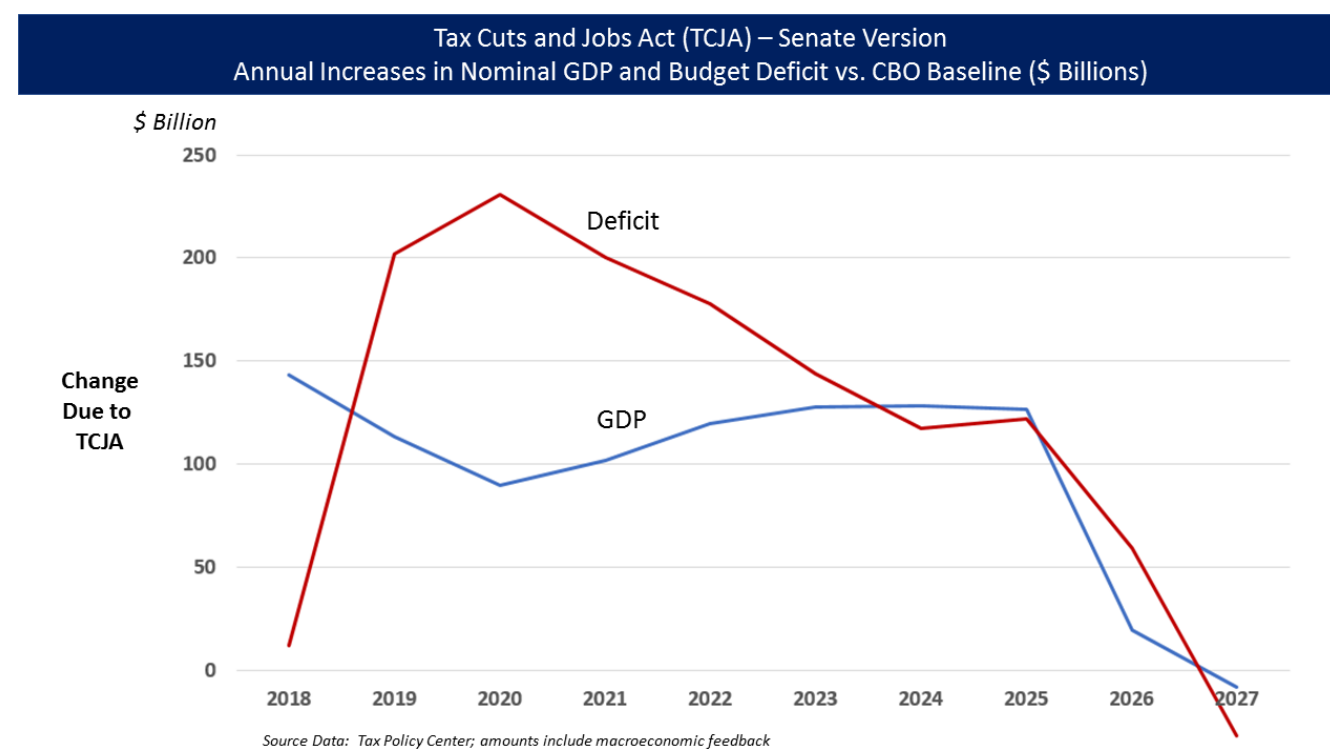

Figure 2: Annual Increases in Nominal GPD and Budget Deficits under Tax Cuts and Jobs Act

Source: Macroeconomic Analysis of the Tax Cuts and Jobs Act as Passed by the Senate Finance Committee. (2017, December 1). Retrieved from https://en.wikipedia.org/wiki/Tax_Cuts_and_Jobs_Act_of_2017

Each year, the Congressional Budget Office issues a set of long-term budget projections - that is, projections of what federal spending, revenues, deficits, and debt will be for the next 30 years under the 
assumption that Job Growth and Tax Cuts stayed the same. At 78 percent of gross domestic product (GDP), federal debt held by the public is now at its highest level since shortly after World War II. If current laws generally remained unchanged, the Congressional Budget Office projects, growing budget deficits will boost that debt sharply over the next 30 years; it will approach 100 percent of GDP by the end of the next decade and 152 percent by 2048 (see Table 1). That amount would be the highest in the nation's history by far. Moreover, if lawmakers changed current law to maintain certain policies now in place - preventing a significant increase in individual income taxes in 2026, for example - the result would be even larger increases in debt. The prospect of large and growing debt poses substantial risks for the nation and presents policymakers with significant challenges (Congressional Budget Office, 2018).

Table 1: Key Projections in CBO's Extended Baseline

\begin{tabular}{|c|c|c|c|c|}
\hline \multicolumn{5}{|l|}{ Percentage of Gross Domestic Product } \\
\hline & 201 & 2019- & 2029- & 2039- \\
\hline & 8 & 2028 & 2038 & 2048 \\
\hline \multicolumn{5}{|l|}{ Revenues } \\
\hline Individual income taxes & 8.2 & 8.9 & 10.1 & 10.7 \\
\hline Payroll taxes & 5.9 & 5.9 & 6.0 & 6.0 \\
\hline Corporate income taxes & 1.2 & 1.5 & 1.4 & 1.4 \\
\hline Other & 1.4 & 1.2 & 1.3 & 1.5 \\
\hline Total Revenues & 16.6 & 17.5 & 18.8 & 19.5 \\
\hline \multicolumn{5}{|l|}{ Outlays } \\
\hline \multicolumn{5}{|l|}{ Mandatory } \\
\hline Social Security & 4.9 & 5.5 & 6.2 & 6.3 \\
\hline Major health care programs & 5.2 & 6.0 & 7.4 & 8.7 \\
\hline Other & 2.6 & 2.5 & 2.3 & 2.1 \\
\hline Subtotal & 12.6 & 13.9 & 15.9 & 17.2 \\
\hline Discretionary & 6.3 & 5.7 & 5.4 & 5.5 \\
\hline Net interest & 1.6 & 2.7 & 3.6 & 5.3 \\
\hline Total Outlays & 20.6 & 22.4 & 24.9 & 27.9 \\
\hline Deficit & -3.9 & -4.9 & -6.1 & -8.4 \\
\hline Debt Held by the Public at the End of the Period & 78 & 96 & 118 & 152 \\
\hline \multicolumn{5}{|l|}{ Memorandum: } \\
\hline \multicolumn{5}{|l|}{ Social Security } \\
\hline Revenues & 4.4 & 4.5 & 4.6 & 4.5 \\
\hline Outlays & 4.9 & 5.5 & 6.2 & 6.3 \\
\hline Contribution to the Federal Deficit & -0.4 & -1.0 & -1.6 & -1.9 \\
\hline \multicolumn{5}{|l|}{ Medicare } \\
\hline Revenues & 1.4 & 1.5 & 1.6 & 1.6 \\
\hline Outlays & 3.5 & 4.3 & 5.7 & 6.8 \\
\hline Offsetting Receipts & -0.6 & -0.8 & -1.0 & -1.3 \\
\hline Contribution to the Federal Deficit & -1.5 & -2.1 & -3.0 & -3.9 \\
\hline Gross Domestic Product at the End of the Period (Trillions of dollars) & 20.1 & 29.8 & 44.1 & 65 \\
\hline
\end{tabular}




\section{Consequences of the Increasing Federal Debt}

Budget experts normally identify four main consequences of rising national debt: lower living standards; policy constraints; less revenue available for other public expenditure; and reduced international influence (Hudson, 2014; Mintz, 2018; Congressional Budget Office 2018). Rising debt tends to be a drag on economic growth because public borrowing crowds out private investment. In other words, a growing portion of savings go towards purchases of government debt, rather than investments in productive capital goods such as factories and computers, leading to lower output and incomes than would otherwise occur.

Second, rising interest payments caused by rising national debt leave less revenue available for other public expenditures, such as spending on infrastructure investment. This means that if higher marginal tax rates were used to pay rising interest costs, savings would be reduced, and work would be discouraged.

Third, if national debt growths too large, the nation has less capacity to respond to emergencies such as the Great Recession that happened in the 2009-2011, and to natural disasters such as the one that passed New Orleans on August 29, 2005. More specifically, increasing federal deficits limit lawmakers' ability to respond to unforeseen events and increase the likelihood of a fiscal crisis - a situation in which the interest rate on federal debt rises abruptly - dramatically increasing the cost of government borrowing.

Fourth, external debt weakens the influence of the United States, because a debtor must strive to accommodate its creditors. Private economists say that our country's status as the biggest debtor has jeopardized its prestige.

\section{Study Implications and Limitations}

Our study is one of earlier practitioner-oriented articles on the impact of the TCJA on the U.S. federal debt. There have been three major tax cuts in the modern US history: Apparently, each of the first two major tax cuts had increased the federal debt substantially Our current study found that the latest major tax cut would definitely increase the U.S. federal debt for years to come so just about Just everybody agrees that US federal debt is on an unsustainable path. Nevertheless, it is important to remember that the first two major tax cuts did not hurt the U.S. economy and the standard of living for Americans. History tends to repeat itself.

Like all analytical research, there are limitations with our study that should be noted. First, our research approach is qualitative and expository. It consults secondary sources of information, such as published academic papers, trade journal articles, and newspapers essays. Some economists use quantitative analysis to supplement other studies and increase forecasting accuracy.

Second, history may not repeat itself. Budget experts normally identify four main consequences of rising national debt: lower living standards, policy constraints, less revenues available for other public expenditure, and reduced international influence. There is no guarantee that such consequences will never happen sometime in the future. If they happened on a large-scale basis, the U.S. may face serious economic problems, such as the great recession of the 2017-2019. In addition, China may replace the U.S. as the world's superpower.

\section{Conclusion}

It is true that the TCJA contains many benefits for Americans: most American taxpayers will enjoy a reduction in their tax liability; the tax code has been simplified; pro-growth provisions will boost economic growth; and many workers can expect their wages to increase. However, we cannot ignore the impact that $\$ 1.5$ trillion in tax cuts will have on the federal debt. While the immediate impacts of government deficits and debt are a matter of controversy, most economists agree that the long-term fiscal outlook for the United 
States requires serious consideration. Budget experts normally identify four main consequences of rising national debt: lower living standards; policy constraints; less revenue available for other public expenditure; and reduced international influence.

In addition, critics charge that the usual combination of tax cut and aggressive government spending did not take place under the TCJA. The government did not try to reduce additional spending for fear of increased deficit and debt. The TCJA came when the United States did not need because the economy was already doing quite well. Economists are concerned about the possibility that the additional money will overheat the economy, thereby trigging the Federal Reserve to raise interest rates in order to fend off potential inflation (Kuehl, 2018).

\section{References}

Bilmes, L. J. (2017, May 25). Iraq and Afghanistan: The US\$6 trillion bill for America's longest war is unpaid. The Conversation. Retrieved from https://theconversation.com/iraq-and-afghanistan-the-us-6trillion-bill-for-americas-longest-war-is-unpaid-78241

CBO Budget and Economic Outlook 2009-2019 (2016, November 21). CBO. Retrieved from https://en.wikipedia.org/wiki/Bush_tax_cuts.

Chowdhury, A. \& Islam, I. (2010, November 9). Is there an optimal debt-to-GDP ratio? Retrieved from https://voxeu.org/debates/commentaries/there-optimal-debt-gdp-ratio

Congress of the United States, Congressional Budget Office (2018, June 26). The 2018 long-term budget outlook. Retrieved from https://www.cbo.gov/publication/53919

Elis, N. (2018, October 5). Deficit soars to $\$ 782$ billion in 2018. The Hill. Retrieved from https://thehill.com/policy/finance/410177-deficit-soars-to-782-billion-in-2018.

Frankel, M. (2017, December 22). How the Tax Cuts and Jobs Act will impact the average American. USA Today. Retrieved from https://www.usatoday.com/story/money/taxes/2017/12/22/how-the-taxcuts-and-jobs-act-will-impact-the-average-american/108822332/

Government (2018, March). Retrieved from: www.treasurydirect.gov

Hudson, W. E. (2014). A Citizen's Guide to Deficits and Debt. New York and London: Routledge: Taylor \& Francis Group. pp.18-20. https://doi.org/10.4324/9780203079447; Mintz, J. (2018, January 24). Global Implications of U.S. Tax Reform. A paper presented at the Munich Seminar, CESifo; Congress of the United States, Congressional Budget Office (2018, June 26). The 2018 long-term budget outlook. Retrieved from https://www.cbo.gov/publication/53919

Kim, S., Crick, T., \& Jia, J. (2008). Which country will be the world economic leader in the next generation: The United States or China? And the North Korean factor. North Korean Review, 4(1), 56-73. doi:10.3172/nkr.4.1.56; Committee for a Responsible Federal Budget (2017, September 11). Q\&A: gross debt versus debt held by the public. Retrieved from http://www.crfb.org/papers/qa-grossdebt-versus-debt-heldpublic?gclid=EAlalQobChMItf3p96bi2gIVRbbACh2bPADgEAAYASAAEgLe6vD_BwE.

Kuehl, C. (2018, May). Tax cuts and jobs acts of 2017. Business and Credit.

Mohsin, S., \& Wood, R. (2018, April 30). Mnuchin sees solid Treasuries demand after record U.S. borrowing. Bloomberg. Retrieved from https://www.bloomberg.com/news/articles/2018-0430/treasury-s-488-billion-in-borrowing-sets-a-first-quarter-record; Wood, R. (2018, April 30). The 
Xu et al. / International Journal of Finance \& Banking Studies, Vol 7 No 4, 2018 ISSN: $2147-4486$

U.S. just borrowed $\$ 488$ billion, a record high for the first quarter. Wyoming Business Report. Retrieved from: http://www.wyomingbusinessreport.com/newsletter_pm/the-u-s-just-borrowedbillion-a-record-high-for/article_fc071c14-4cb3-11e8-b527-e3cdaf992b2e.html

Neal, T. (2003, February 3). Bush releases proposed $\$ 2.23$ trillion budget. Retrieved from http://www.washingtonpost.com; The Council of Economic Advisors (2017, February). The Economic report of the President to Congress, Washington D.C., U.S. Government Printing Office.

Preliminary details and analysis of the Tax Cuts and Jobs Act (2017, December 18). Tax Foundation. Retrieved from https://taxfoundation.org/final-tax-cuts-and-jobs-act-details-analysis/

Schroder, R. (2018, February 13). The U.S. is now over $\$ 20$ trillion in debt - here's how it got there. Market Watch. Retrieved from https://www.marketwatch.com/story/heres-how-the-us-got-to-20-trillion-indebt-2017-03-30

The Budget and Economic Outlook: 2018 to 2028 (2018, April 9). Retrieved June 23, 2018.

The Council of Economic Advisors (1985-1989). Economic report of the Congress. Washington. The United States Government Printing Office.

The Council of Economic Advisors (2018). Chapter 1 taxes and economic growth. Economic Report of the President, p.32. 